\title{
3D reconstruction of salt movements within the deepest post-Permian structure of the Central European Basin System - the Glueckstadt Graben
}

\section{Y. Maystrenko*, U. Bayer \& M. Scheck-Wenderoth}

GeoForschungsZentrum Potsdam, Section 4.3, Telegrafenberg, 14473 Potsdam, Germany

* Corresponding author. Email: yuram@gfz-potsdam.de

Manuscript received: March 2006; accepted: August 2006

\begin{abstract}
The Glueckstadt Graben is a prominent structure of the Central European Basin System, where the sedimentary patterns are extensively affected by Permian salt movements. The relations of the sedimentary patterns to salt structures have been analyzed through present-day distributions of sediments. In addition, a three-dimensional backward modelling approach has been applied to determine the original salt distribution in response to the unloading due to sequential backstripping of the stratigraphic layers. The results of the modelling reveal the thickness distribution of the Permian salt for 5 time intervals from the end of the Triassic to present day. Spatial agreement has been found between the development of the depleted zone of the Permian salt through time and the observed distribution of the maximum subsidence for the different stratigraphic units above the salt. The sedimentation centres for each time interval are always located above the zone of reduced or depleted Permian salt. In the central part of the Glueckstadt Graben, the depletion occurred already in the Triassic and perfectly correlates with the thickest Triassic. During the Jurassic, Cretaceous and Tertiary, the areas of depleted Permian salt shifted towards the basin flanks, and the same occurred with the centres of maximum sediment deposition. Thus, the results of the modelling strongly support the conclusion that salt withdrawal has played a major role during the Meso-Cenozoic evolution of the Glueckstadt Graben and that the progressive depletion of the Permian salt layer, from the central part towards the margins, created the large part of the accommodation space for sedimentation in addition to tectonic subsidence.

Furthermore, our study has several important implications for salt behaviour in different tectonic settings. In general, the results of modelling indicate a good correlation between the main phases of salt movements and tectonic events in the area under consideration. During the Triassic, the first stage of diapirism in the Glueckstadt Graben occurred within the central part of the basin. Regional extension may have triggered reactive diapirism and caused the formation of the deep primary rim synclines. Once the salt structures had reached the critical size, buoyancy forces supported their continued growth until the Jurassic when extension-induced regional stresses once more affected the Glueckstadt Graben. The results of the modelling indicate very little salt activity during the late Early Cretaceous-early Late Cretaceous when the area of the Glueckstadt Graben was tectonically silent. Therefore, our study supports the concept of tectonically induced salt movements which can be interrupted during the absence of tectonic forces. Salt movements were reactivated in the marginal troughs by compressional forces during the latest Late Cretaceous-Early Cenozoic. Paleogene-Neogene salt withdrawal led to the growth of N-S oriented salt structures mainly at the margins of the basin. This phase of salt tectonics correlates temporally with almost W-E extension. This indicates a renewed change in tectonic regime after Late Cretaceous-Early Cenozoic compression.
\end{abstract}

Keywords: Triassic graben, salt tectonics, 3D modelling, NW Germany

\section{Introduction}

Many analogue and numerical models have been constructed in order to investigate salt behaviour under different tectonic settings and load conditions. Modelling approaches of salt movements have focussed on different aspects of salt tectonics, such as a combination of two major effects on salt flow by: (1) fault tectonics at the base of the salt and/or overburden as a triggering mechanism; and (2) changing sediment load distributions in time and space. The results of analogue experiments and numerical simulations demonstrate that the viscous salt is very responsive to variable sediment loading 
and fault tectonics (e.g. Woidt, 1978; Schmeling, 1987; Roemer \& Neugebauer, 1991; Vendeville \& Jackson, 1992; Koyi et al., 1993; Poliakov et al., 1993; Daudre \& Cloetingh, 1994; Koyi, 1998; Kaus \& Podladchikov, 2001). Most of these experiments were performed in terms of two-dimensional studies. However, three-dimensional modelling has to be used to investigate salt flow phenomena. Recently, a few models have been implemented in full 3D (e.g. Guglielmo et al., 1999; Scheck et al. 2003a, b; Ismail-Zadeh et al.; 2004). 3D visualization of the results of analogue modelling have helped to elucidate the complex geometry of salt diapirs (Guglielmo et al., 1999), demonstrating changes of sedimentation, deformation, and underlying salt thickness through time. A full 3D numerical approach was applied by Scheck et al. (2003a, b) for the NE German Basin, considering salt flow as a consequence of spatially changing overburden, isostatic response and sediment compaction. Ismail-Zadeh et al. (2004) investigated the evolution of salt structures both forwards and backwards in time by means of 3D numerical finite-element models.

Here, we present the results of three-dimensional backward modelling of salt movements within the Glueckstadt Graben (GG) by use of a software developed at the GeoForschungsZentrum Potsdam (Scheck et al., 2003a). Structurally, the GG is characterized by SW-NE elongated salt walls which formed during post-Permian times due to Permian salt withdrawal (Figs 1, 2a). It is obvious that the presence of the huge salt walls complicates the basin evolution. Therefore, a threedimensional model of the GG (Fig. 2b) has been constructed to study the basin evolution in detail. A 3D backward modelling approach has been used to determine the salt distribution in response to unloading due to sequential backstripping of the stratigraphic layers. Therefore, the major objective of this work is to reconstruct the paleo-positions of the Permian salt and to understand the factors which controlled the main phases of rapid subsidence within the GG.

\section{Evolution of the Glueckstadt Graben in relation to regional tectonics}

The GG is a central, NNE-SSW trending, segment of the Central European Basin System (CEBS; Fig. 1), where thick sediments $(>11,000 \mathrm{~m}$ ) accumulated during the Permian, Mesozoic and Cenozoic. The upper part of the Permian succession (mainly Zechstein) comprises thick evaporite deposits consisting of salt and subordinate carbonates and anhydrites. During postPermian times, the sedimentary fill of the CEBS was extensively affected by salt movements. The major stages of salt movements occurred during the Triassic, creating significant space for

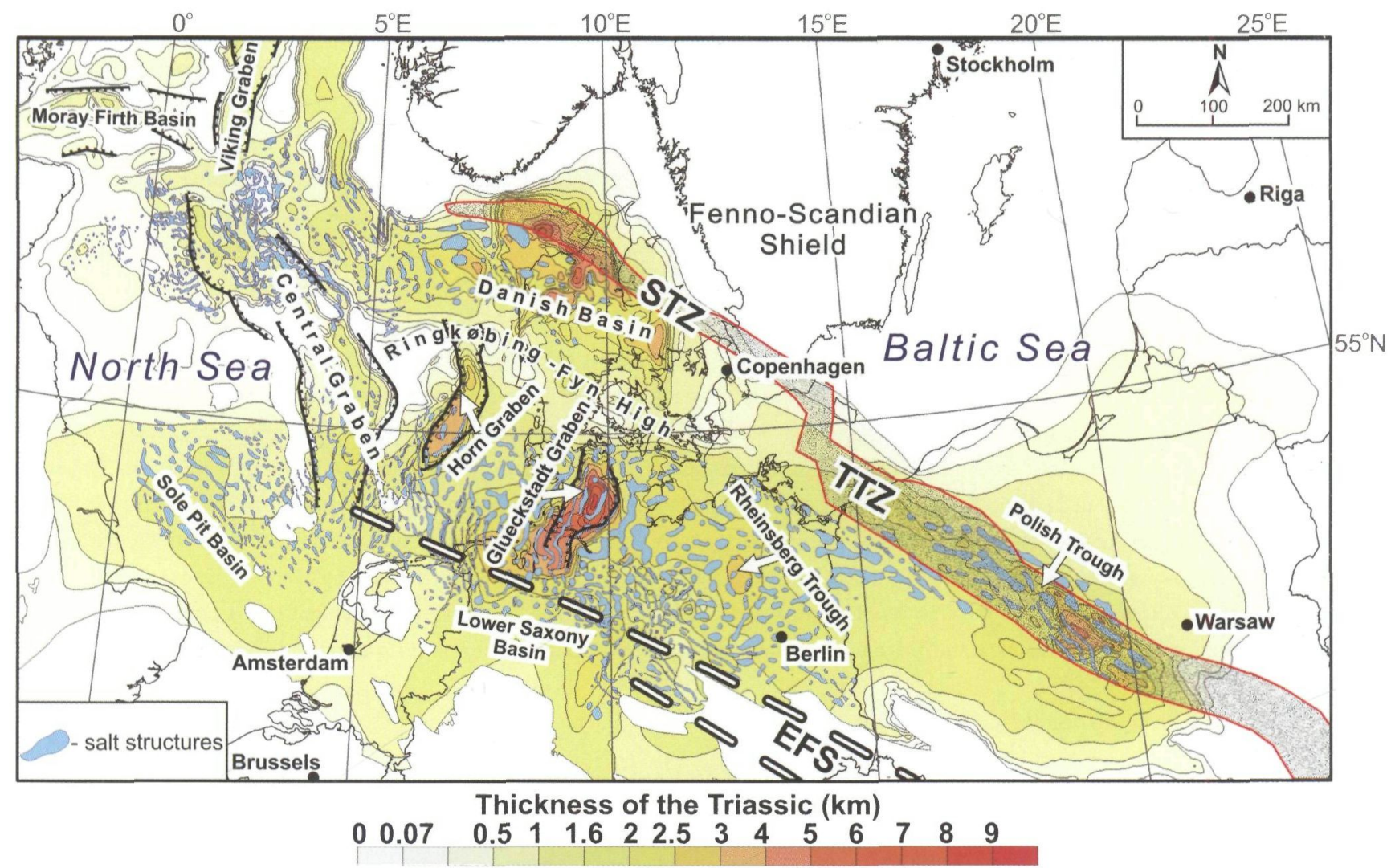

Fig. 1. Location of the study area in relation to major Triassic subsidence centres within the Central European Basin System (compiled after Van Hoorn, 1987; Ziegler, 1990; Britze \& Japsen, 1991; Vejbaek \& Britze, 1994; Lockhorst, 1998; Pharaoh, 1999; Baldschuhn et al., 2001; Evans et al., 2003; Scheck et al., 2003a; Dadlez, 2003; NITG, 2004; Lamarche \& Scheck-Wenderoth, 2005).

Major structural elements - EFS: Elbe Fault System, STZ: Sorgenfrei-Tornquist Zone, TTZ: Teysseyre-Tornquist Zone. 

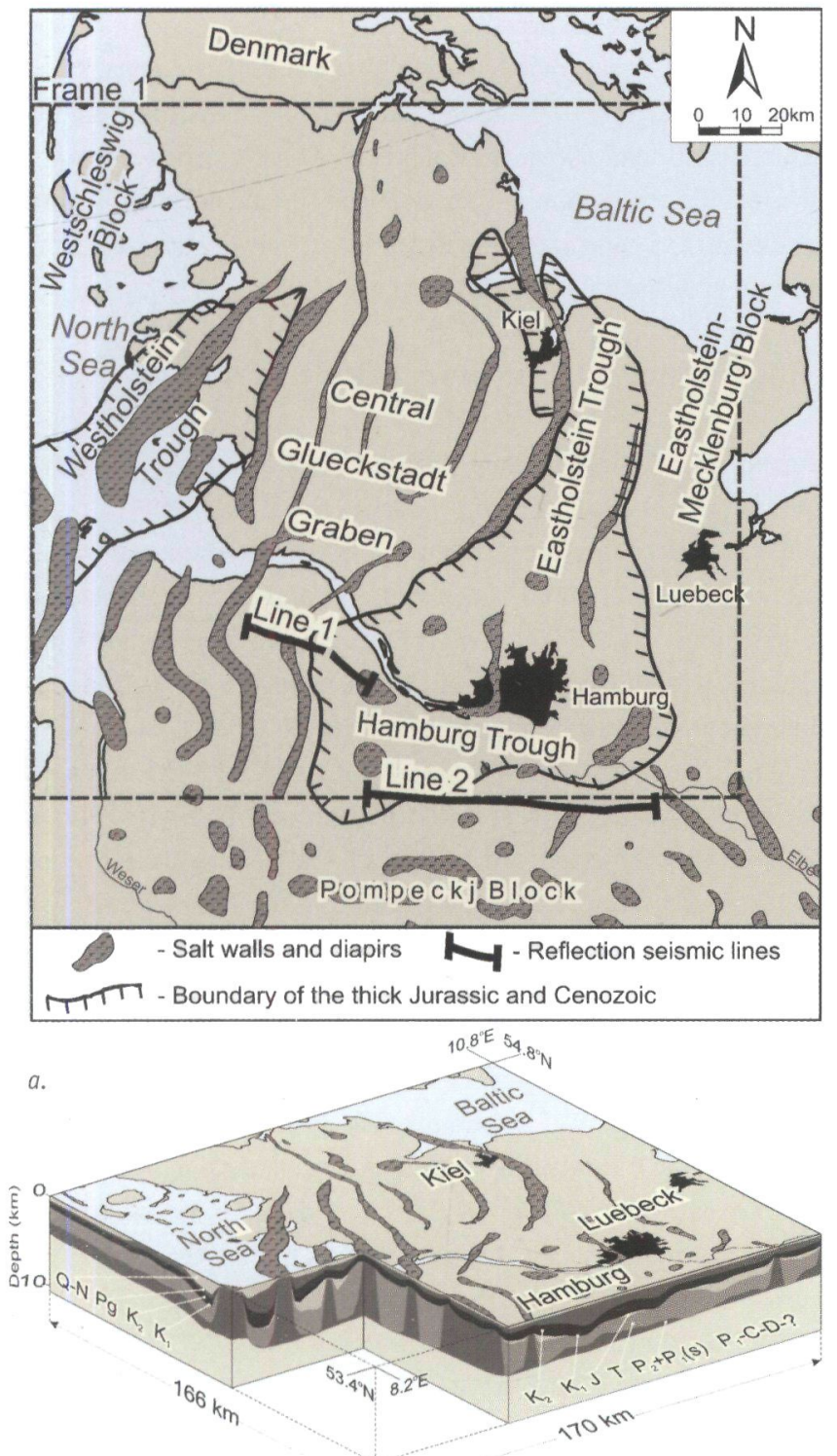

b.

Fig. 2. a. Tectonic map of the Glueckstadt Graben with location of the seismic lines (position of salt domes by Baldschuhn et al., 2001); b. 30 structural model of the Glueckstadt Graben and adjacent areas (for location see Frame 1 in Fig. 2a). Stratigraphic key: $P_{1}-C-D=$ Undivided Lower Permian (Rotliegend), Carboniferous and Devonian deposits; $P_{2}+P_{1}(s)=$ upper part of the Lower Permian and Upper Permian (undivided Zechstein plus salt-rich Rotliegend); $T=$ Triassic; $J=$ Jurassic; $K=$ Cretaceous; $P g=$ Paleogene; $Q-N=$ Quaternary-Neogene.

additional sedimentation. This period of salt tectonics was associated with extension, reflecting a discrete pulse of tectonic activity in the Triassic (Ziegler, 1990; Vejbaek, 1990; Kockel, 2002; Scheck et al., 2003a; Krzywiec, 2004; Maystrenko et al. 2005a). At the regional scale, the Triassic corresponds to a period of global plate reorganization, marking the beginning break-up of Pangea (Ziegler, 1990). Figure 1 shows that the most intense Triassic subsidence occurred in the different subbasins surrounding the Ringkøbing-Fyn High, in the Horn
Graben (Clausen \& Pedersen, 1999; Baldschuhn et al., 2001), the GG (Baldschuhn et al., 2001; Maystrenko et al., 2005a) and the Danish Basin (Britze \& Japsen, 1991). Another centre of Triassic subsidence is located within the Polish Trough where the thickness of Triassic reaches up to $5000 \mathrm{~m}$ (Dadlez, 2003). The Sole Pit Basin, the Central Graben and the Rheinsberg Trough are characterized by minor thickening of the Triassic strata (Van Hoorn, 1987; Ziegler, 1990; Evans et al., 2003; Scheck et al., 2003a, b). By far the thickest Triassic succession is observed in the GG reaching about $9000 \mathrm{~m}$. After the Triassic, a rifting phase is observed in the Late JurassicEarly Cretaceous in several basins, such as the Lower Saxony Basin (Betz et al., 1987; Jordan \& Kockel, 1991), in the Central North Sea Rift (0akman \& Partington, 1998; Erratt et al., 1999; Nielsen, 2002; Moeller \& Rasmussen, 2003), and in the Central Basin and West Netherland Basin (Van Wijhe, 1987).

Within the GG, three deep troughs formed marginal to the Triassic graben structure during the Early and Middle Jurassic (Boigk, 1981; Baldschuhn et al., 2001; Maystrenko et al., 2005a). Subsequently, the GG area was affected by regional erosion due to uplift or sea level fall during Late JurassicEarly Cretaceous time (Jaritz, 1969, 1980; Brink et al., 1992; Baldschuhn et al., 2001; Maystrenko et al., 2005a, b). During the latest Cretaceous, superposed far field stresses induced by the Alpine orogen and the Atlantic rift affected the entire CEBS in terms of compression. The strongest compressional deformations were localized along the Sorgenfrei-Tornquist Zone, the Teisseyre-Tornquist Zone and the Elbe Fault System, causing strong erosion within these areas (Ziegler, 1990; Scheck et al., 2002; 0tto, 2003; Scheck-Wenderoth \& Lamarche, 2005; Mazur et al., 2005). The Cenozoic was again characterized by rapid subsidence of the Central North Sea (Sclater \& Christie 1980; Jordt et al. 1995; Garetsky et al. 2001; Nielsen, 2002) and by the development of Cenozoic rifts such as the Rhine, Leine and Eger grabens (Ziegler, 1992; Evans et al., 2003). During the Cenozoic, the GG was affected by normal faulting and by rapid subsidence (Maystrenko et al., 2005a, b), simultaneously with the North Sea basins.

\section{Previous work, data and methods}

The basin structure and fill of the GG have been systematically studied since the beginning of the last century, mainly in the view of oil and gas exploration. Thereby, many details have been published, from which we highlight some related to our study. Based on well and early seismic data from NW Germany, Trusheim (1960) postulated a kinematic concept for the relation between sedimentary patterns adjacent to salt structures and the evolution of salt structures. At the basin scale, Sannemann (1968) has observed that salt diapirs of the GG spread in time becoming younger by moving away from the axial part towards the basin flanks. For this phenomenon he introduced the term 'salt-stock families'. Jaritz $(1969,1980)$ 
has focussed at the regional Late Jurassic-Early Cretaceous erosional event, providing first-order estimations of the thickness of eroded Jurassic sediments. The regional structure of the GG has been discussed by Best et al. (1983), while a gravity study was done by Dohr et al. (1989), providing insight into the deep structure of the GG. The major aspects of the development and structure of the GG have been discussed by Brink et al. (1990, 1992), summarizing the evolution of the GG from Permian times until present day. The next step towards an integrated study of the GG was done by Baldschuhn et al. $(1996,2001)$ who provided the Geotectonic Atlas of NW Germany. Kockel $(2002,2003)$ described the major evolutionary steps of NW Germany. At the beginning of this century, the area under consideration became of additional interest because seismic and well data were provided by the oil and gas industry through the German Society for Petroleum and Coal Science and Technology (DGMK) in frame of the DFG-SPP 1135 'Dynamics of sedimentary systems under varying stress conditions by example of the Central European Basin system'. Based on these data, several results have been published concerning the structure and evolution of the GG with focus on salt tectonics (Maystrenko et al., 2005a, b), recent movements (Lehne \& Sirocko, 2005), and thermal maturity (Rodon \& Littke, 2005). In this paper, the evolution of salt structures of the GG has been studied backwards in time by means of $3 \mathrm{D}$ numerical modelling.

As the input data for 3D modelling, a 3D structural model (Fig. 2b) has been constructed for the GG and adjacent areas from $53.4^{\circ} \mathrm{N}$ to $54.8^{\circ} \mathrm{N}$ latitude and $8.2^{\circ} \mathrm{E}$ to $10.8^{\circ} \mathrm{E}$ longitude (Fig. 2b). This 3D structural model was derived from depth maps of the digital version of the Geotectonic Atlas of NW Germany (Baldschuhn et al. 1996, 2001). The data were gridded with a cell resolution of $2 \times 2 \mathrm{~km}$. In some areas, a 3D model has been supplemented by use of well data and interpreted depth converted seismic sections. The model includes seven layers from the Rotliegend to the Quaternary. The lowest one is the salt-rich Rotliegend plus the Zechstein, overlain by Triassic, Jurassic, Lower Cretaceous, Upper Cretaceous, Paleogene and Quaternary-Neogene.

The theory of 3D modelling has been described in details by Scheck \& Bayer (1999) and by Scheck et al. (2003b). Here we only elucidate the basic concept of modelling. Basic assumptions behind the concept are that the 3D backward modelling of the development of salt structures requires several steps. The first step is to remove the sediments above the selected stratigraphic level. Then the remaining sediments are decompacted. Subsequently, redistribution of the salt is calculated for the reduced overburden load. The behaviour of salt is assumed to be similar to a viscous fluid and salt volume is conserved. After salt redistribution, a load balance at the base salt is achieved in the sense that salt and overburden are in hydrostatic equilibrium. Finally, the isostatic response of the entire model is calculated according to the new mass distribution with an Iceberg approach. In other words, the new load conditions after salt redistribution are isostatically compensated at the crustal level. Therefore, salt flow depends only on the sedimentary load above the salt layer. The described sequence of modelling was applied to every step of backstripping to reconstruct a reasonable geometry of salt structures from present day back to the end of the Triassic.

\section{Subsidence in the Glueckstadt Graben}

During the Meso-Cenozoic, the GG was affected by three phases of strong salt tectonics, during the Triassic, the Jurassic and the Cenozoic (e.g. Trusheim, 1960; Sannemann, 1968; Brink et al., 1990, 1992; Baldschuhn et al, 2001; Kockel, 2002; Maystrenko et al., 2005b). Here, we use two key seismic lines to illustrate the influence of salt movements on subsidence during the mentioned phases of salt tectonics.

The first example (line 1, Fig. 3) runs through the marginal parts of the Central Glueckstadt Graben and Hamburg Trough crossing an elongated salt wall in the NW and a near-surface situated salt diapir in the SW (see Fig. 2a). The NW salt wall provides an example for Late Triassic (Keuper) piercing of the overburden while the SE salt diapir shows Cenozoic (Paleogene) piercing. Internally, the uppermost Middle-Upper Triassic (Keuper) has a very complex seismic pattern around the salt wall. The thickness of the Keuper $\left(\mathrm{T}_{2-3}\right)$ decreases towards the south-east, and the thickest sedimentary succession is observed directly near the salt wall (Fig. 3). The lower Keuper sediments are truncated at their top at both sides of the salt wall. Furthermore, at the north-western flank of the salt wall the lower Keuper sediments are north-westward tilted while younger Keuper strata are characterized by predominance of south-eastward inclination. The difference between tilt angles, observed truncation of the Muschelkalk $\left(\mathrm{T}_{2}\right)$ and the lower Keuper indicate piercement of the overburden during Keuper times. The presence of internal on- and toplaps within the Keuper succession indicate that deposition took place simultaneously with salt movements. Steep onlap within the Keuper sequence at the NW flank of the salt wall (see arrows in Fig. 3) can be explained by extruded Permian salt which flowed from the salt wall onto the paleobasin floor.

The evolution of the salt diapir in the SE part of line 1 is different from the salt wall development. The Muschelkalk is characterized by slight thinning towards the salt diapir in the south-east. This thinning of the Muschelkalk strata could have occurred due to initial salt movements already in the Muschelkalk when a salt pillow started to form in the place of the present-day diapir. The strong stratigraphic thinning of the Keuper towards the diapir suggests that the salt was near the paleosurface, but did not pierce its overburden at that time. It is important to note, however, that the strong thinning of the Keuper could be partially a result of erosion during the Late Jurassic-Early Cretaceous regional interruption of 

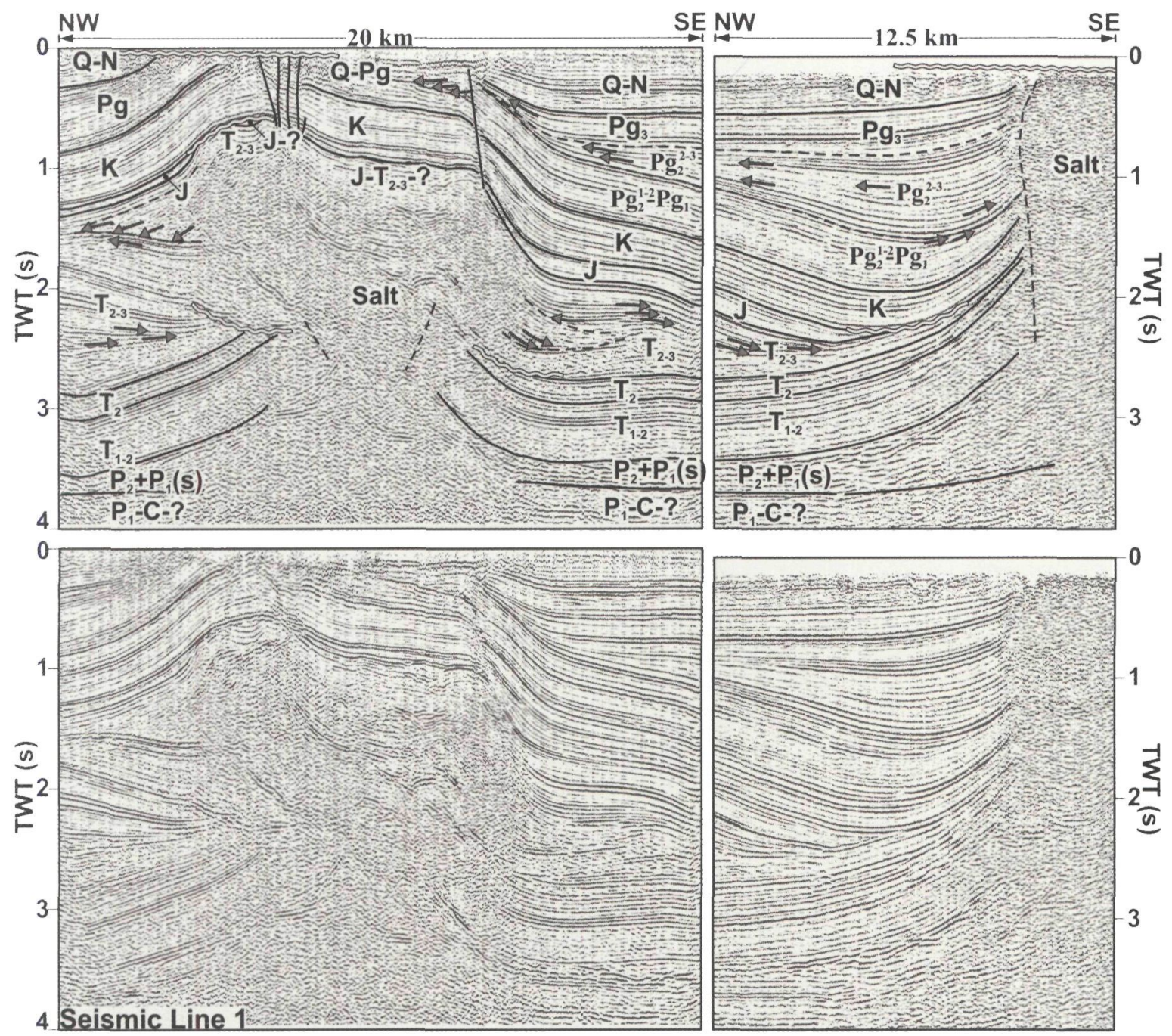

Fig. 3. Seismic profile 1 consisting of two closely located seismic lines. Two salt structures with different time of salt piercing are shown: Late Triassic (Keuper) on the left and Cenozoic (Paleogene) piercing on the right. Visible erosional unconformities are indicated by wavy lines; grey arrows show onand toplap of the reflection terminations. Stratigraphic key: $P_{1}-C=$ Undivided Lower Permian (Rotliegend) and Carboniferous deposits; $P_{2}+P_{1}(s)=$ upper part of the Lower Permian and Upper Permian (undivided Zechstein plus salt-rich Rotliegend); $T_{1-2}=$ Lower Triassic and lowermost part of Middle Triassic (Buntsandstein); $T_{2}=$ Middle Triassic without uppermost and lowermost parts (Muschelkalk); $T_{2-3}=$ uppermost part of Middle Triassic and Upper Triassic (Keuper); $J=$ Jurassic; $K=$ Cretaceous; Pg $=$ Paleogene; $Q-N=$ Quaternary-Neogene. See Fig. 2 a for location.

sedimentation. The pillow stage of the diapir development continued during the Cretaceous $(\mathrm{K})$ and Early EocenePalaeocene $\left(\mathrm{Pg}_{2}{ }^{1-2}-\mathrm{Pg}_{1}\right)$, causing stratigraphic thinning of the sediments towards the crest of the salt anticline. During the Middle Eocene $\left(\mathrm{Pg}_{2}{ }^{2}\right)$, the centre of deposition had moved towards the salt structure, leading to a main stage of secondary rim syncline formation during the Middle-Late Eocene $\left(\mathrm{Pg}_{2}{ }^{2-3}\right)$, when the area around the salt diapir rapidly subsided due to salt withdrawal from a limb of the former salt pillow. The changes of onlap direction from south-eastward to northwestward demonstrate a rapid reversal of the depositional pattern in close proximity to the growing salt diapir. This reversal of thicknesses corresponds to the time interval between the latest Early Eocene and the earliest Middle Eocene when the salt had pierced the overburden.
The record of various styles and intensities of salt-driven subsidence for different stratigraphic levels makes line 2 (Fig. 4) a key seismic profile for understanding overburden deformation processes. This west-east running line shows the structure of the southern margin of the Hamburg Trough. Two salt layers have been interpreted along this line: the salt-rich Rotliegend $\left(P_{1}(s)\right)$ and the Upper Permian layer of Zechstein salt $\left(\mathrm{P}_{2}\right)$. The salt-rich Rotliegend sediments are preserved as a huge flat blanket without prominent deformation in the western and eastern parts of the profile (Fig. 4). In the central part, the upper Rotliegend deposits reflectors generally become chaotic and wormy beneath the area of the Keuper depocentre. This indicates that upper Rotliegend salt was involved, together with the Zechstein salt, in the formation of the salt stock located south of the profile (see Fig. 2a). 

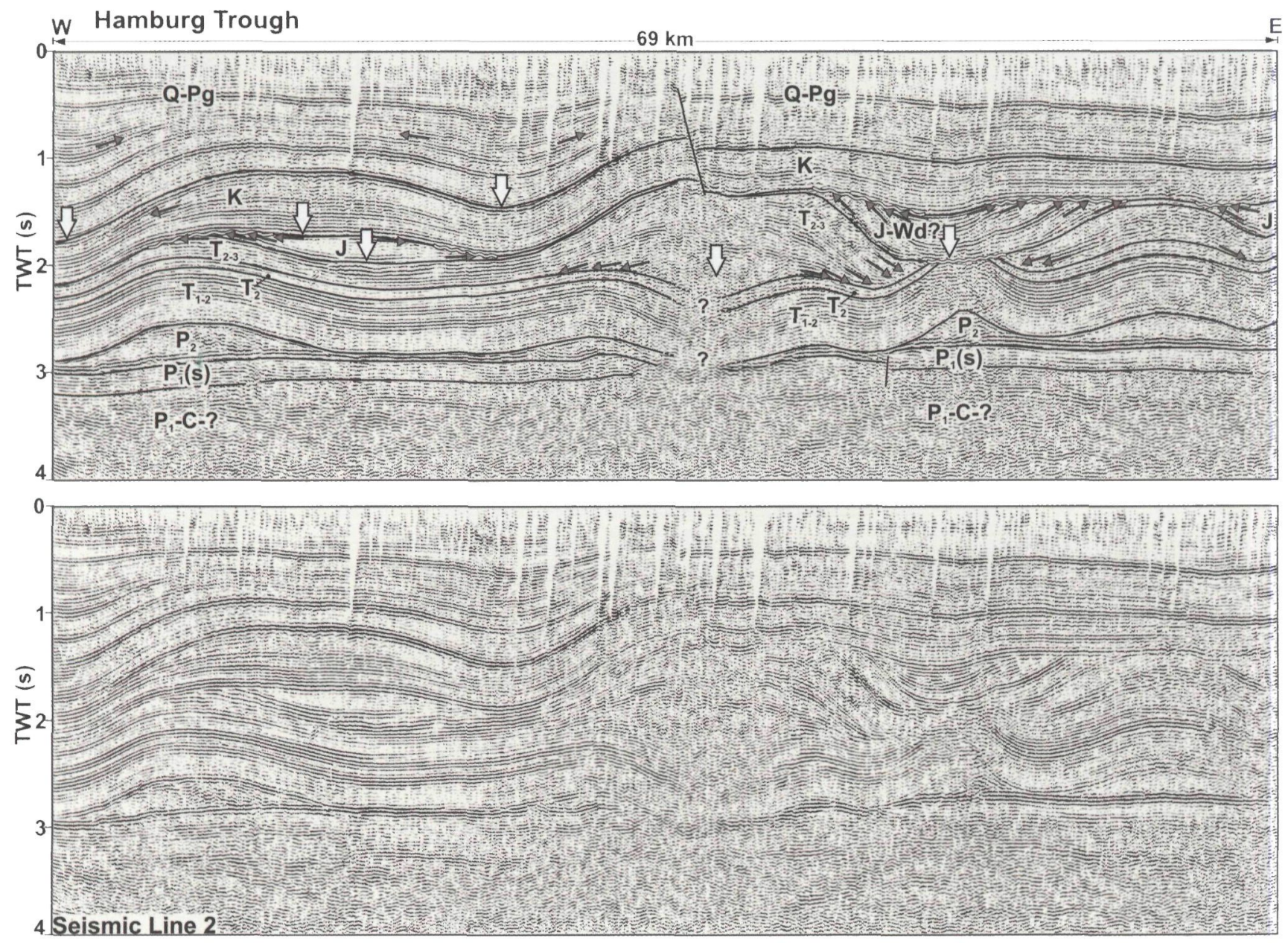

Fig. 4. Interpreted seismic profile 2 showing the record of various styles and intensity of salt-driven subsidence for different stratigraphic levels. The visible erosional unconformity is indicated by wavy line; grey arrows show on-and toplap of the reflection terminations; white arrows indicate the depocentres of sedimentation. Stratigraphic key: $P_{1}-C=$ Undivided Lower Permian (Rotliegend) and Carboniferous deposits; $P_{1}(s)=$ salt-rich Rotliegend; $P_{2}=$ Zechstein; $T_{1-2}=$ Lower Triassic and lowermost part of Middle Triassic (Buntsandstein); $T_{2}=$ Middle Triassic without uppermost and lowermost parts (Muschelkalk); $T_{2-3}=$ uppermost part of Middle Triassic and Upper Triassic (Keuper); $\mathrm{J}=$ Jurassic; Wd = lowermost Lower Cretaceous (Wealden); $K=$ Cretaceous; $Q-P g=$ Quaternary- Paleogene. See Fig. 2 a for location.

Zechstein deposits are generally thin in consequence of postdepositional salt migration. As a result, salt structures, such as the three salt pillows and the mentioned salt diapir formed.

The Buntsandstein-Muschelkalk $\left(\mathrm{T}_{1-2}-\mathrm{T}_{2}\right)$ deposits have an almost constant thickness of about $0.6 \mathrm{~s}$ TWT with the exception of the salt anticline within the eastern part, where the Buntsandstein $\left(\mathrm{T}_{1-2}\right)$ and Muschelkalk $\left(\mathrm{T}_{2}\right)$ are truncated in the crest. The western part of the line is characterized by the presence of thin Keuper deposits $\left(\mathrm{T}_{2-3}\right)$, which concordantly covers the underlying Muschelkak and Buntsandstein. In contrast, the internal Keuper reflections are not in phase with the underlying bedding within the area of thickened Keuper in the central part of the section. There, the Keuper sequence is extremely thickened up to $0.9 \mathrm{~s}$ TWT in comparison to $0.24 \mathrm{~s}$ TWT on the western margin. The thickened Keuper sequence is characterized by the presence of clinoforms onlapping onto the top of Muschelkalk. These baselaps indicate a main phase of salt movements that occurred at the beginning of Keuper times. In addition, the onlap of the Keuper onto the Muschelkalk demonstrates that structural highs were formed due to salt movements. Some of these structural highs persisted until the Jurassic. Figure 4 shows one of these highs where thick Jurassic sediments discordantly cover eroded Buntsandstein and Muschelkalk sediments at the crest of the Permian salt anticline. Jurassic strata form three depocentres, and at the top are characterized by an erosional unconformity. Clearly, some of the Jurassic sediments have been eroded (Fig. 4), implying a major hiatus at the base of the Cretaceous. On the other hand, thickening of the Jurassic sediments within the depositional centres does not necessarily indicate the distribution of an equally thick Jurassic layer prior to the Late Jurassic - Early Cretaceous erosion in this area. The preserved depocentres are rather a consequence of progradation of clastic wedges following salt outflow. This is illustrated by the change 
from more steeply-dipping seismic reflection patterns in the older Jurassic strata to an almost horizontal reflection pattern within the youngest Jurassic sediments, indicated by arrows within the Jurassic sequence in Fig. 4.

The Cretaceous covers an erosionally leveled surface and display only minor thickness variations, from $0.4 \mathrm{~s}$ up to $0.6 \mathrm{~s}$ TWT. In contrast, the Cenozoic shows again synsedimentary thickness variations. Along line 2, the Cenozoic sequence reaches a thickness of $1-1.8 \mathrm{~s}$ TWT. A high-angle normal fault cuts the Cretaceous and the Cenozoic through the anticline in the centre of the profile (Fig. 4). This fault divides the line into two segments. The eastern segment is characterized by approximately subparallel Cretaceous and Cenozoic reflections. A distinct angular unconformity separates them from folded Triassic and Jurassic deposits. In contrast, the Cretaceous and Cenozoic successions are folded west of the fault. Therefore, this seismic line illustrates that the axial parts of the thickened sediments at the different stratigraphic levels are rarely vertically aligned (see white arrows in Fig. 4). They shifted in time and in space. For instance, two segments of thick Keuper are separated by a thick Jurassic sequence (Fig. 4), and both thick successions are covered by Cretaceous and Cenozoic with almost constant thickness. Furthermore, an unusual extensive thickening of the Cretaceous strata is observed between two Cenozoic depressions in the western part of the line. These two Cenozoic depressions are characterized by thickening of strata, indicating rapid subsidence in comparison to other parts of the section. The thickened Cretaceous is underlain by thick Jurassic but without vertical alignment of the axes of maximum thickness. Furthermore, deformations of the overburden are observed above the approximately flat base Zechstein and an equally flat salt-rich Rotliegend layer over almost the entire line. Only in the central part, the base salt appears disturbed below the axial part of the Keuper depocentre. This shows that the salt cover was deformed due to salt movements and that the Permian salt layers decoupled deformation of the overburden from the strata below. Thus, the observed thickening of the sediments must have been associated with simultaneous salt movements.

Based on the observations, we conclude that the deposition of thick successions of the Triassic, Jurassic, and Cenozoic was partially controlled by gradual withdrawal of Permian salt from the source layer, initialized in the Triassic.

\section{D backstripping}

\section{Present-day and restored thickness maps}

Modelling difficulties arise when input data contain layers, which were affected by post-depositional changes. Such changes occur as a result of erosion due to salt tectonics, regional uplift or sea level fall. Simple backstripping to the partially eroded stratigraphic interval does not produce the load conditions existing before erosion. Therefore, salt redistribution will not provide a correct geometry for this stratigraphic interval. Scheck et al. (2003b) solved this problem by re-establishment of restored thickness maps prior to post-depositional changes.

Local post-depositional erosion of sediments in the GG occurred during the main phases of salt tectonics, in the Triassic, the Jurassic, and the Tertiary. In addition, the area under consideration was affected by regional Late JurassicEarly Cretaceous erosion. Therefore, part of the sedimentary sequence has to be re-established prior to salt redistribution for selected time steps. In order to solve this problem, reconstructed sediment distributions were introduced as additional input data in terms of 'initial' thickness maps. The reconstruction of the primary isopach maps was based mainly on the interpretation of seismic lines and published structural data from the GG (Baldschuhn et al., 1996; Baldschuhn et al., 2001; Kockel, 2003). We considered primary sediment distributions for the Triassic, the Jurassic, the Lower Cretaceous, the Upper Cretaceous and the Paleogene.

The present-day and reconstructed thickness maps of the Triassic are shown in Fig. $5 \mathrm{a}, \mathrm{b}$. The Triassic is one of the thickest stratigraphic units in the 3D structural model (Fig. 5a). A broad area of thick Triassic sediments occupies the whole Central Glueckstadt Graben and is characterized by a gradual increase of thickness from less than $3500 \mathrm{~m}$ at the margins to more than $6500 \mathrm{~m}$ towards the basin centre. The maximum present-day thickness of the Triassic in the axial part of the GG is characterized by a salt wall-bounded oval zone with a predominant SSW-NNE trend, within which the thickness ranges from 6500 to more than $9000 \mathrm{~m}$. Within the basin flanks and marginal troughs, the Triassic thickness varies between 1300 and $2300 \mathrm{~m}$ in general with local maxima of up to $3000 \mathrm{~m}$. Reduced sediment thickness is present in the area of some salt structures, which are related to syndepositional salt movements in the Triassic. Most isopachs of the Triassic delineate the contours of salt structures in the horizontal plane (Fig. 5a), indicating a strong influence of salt movements on the distribution of the Triassic.

Both well and seismic data show that Triassic sediments were affected by Late Jurassic-Early Cretaceous regional erosion. During this erosion, Triassic deposits were eroded on the crests of salt structures where sediments were elevated higher than elsewhere (Baldschuhn et al., 2001; Maystrenko et al., 2005b). In addition, post-Triassic salt movements pierced Triassic sediments within the Westholstein, Eastholstein and Hamburg troughs. These effects were considered for the reconstruction of the initial distribution of the Triassic sediments. To produce a reconstructed thickness map of the Triassic, the present-day thickness distribution (Fig. 5a) has been corrected by closing the gaps where the Triassic was pierced or eroded post-depositionally. The greatest difference between the present-day and the reconstructed maps is visible 

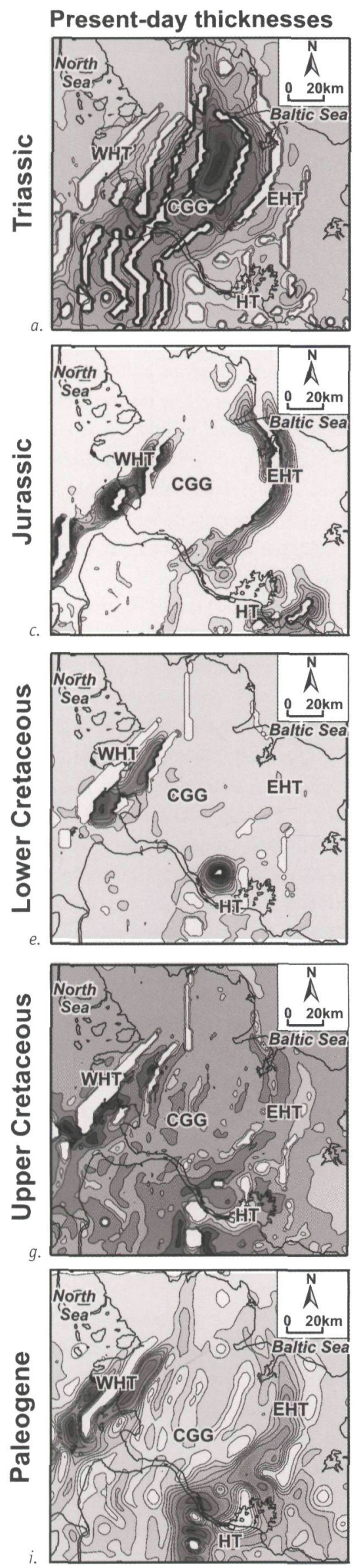

\section{Reconstructed thicknesses}
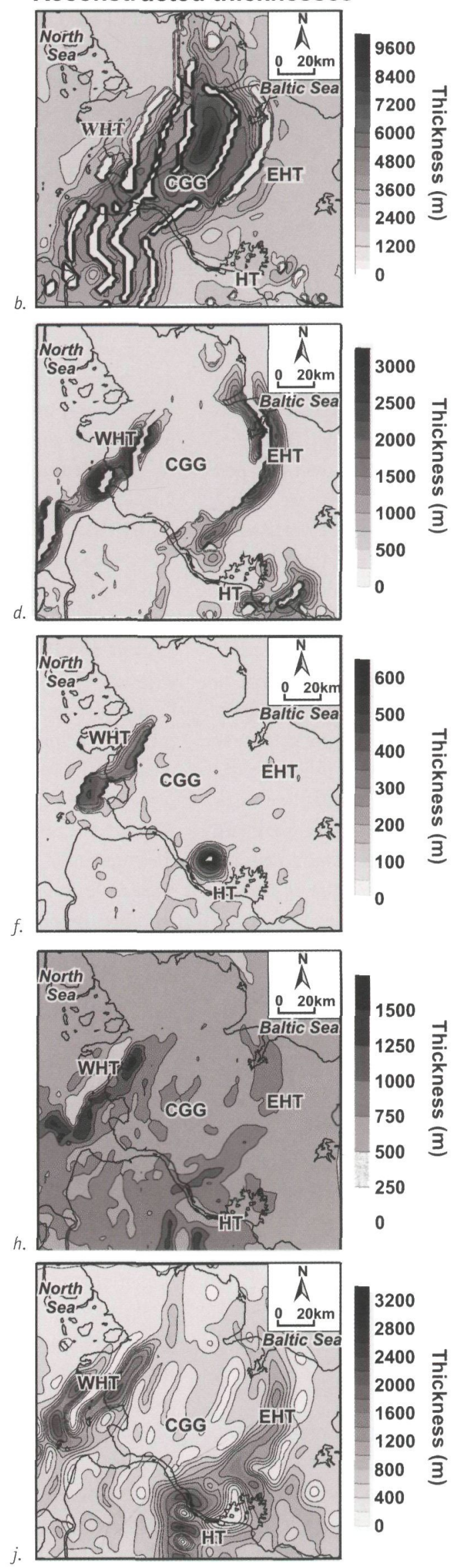

Fig. 5. Present-day (left column) and reconstructed (right column) thickness maps of the stratigraphic units used in the $3 D$ structural model. CGG - Central Glueckstadt Graben, EHT - Eastholstein Trough, HT - Hamburg Trough, WHT Westholstein Trough. 
within the marginal troughs. On the reconstructed map, the distribution of the Triassic sediments has been re-established within the Westholstein, Eastholstein and Hamburg troughs for the pre-Jurassic state. Therefore, the effect of the postTriassic salt piercing is not expressed in this map (Fig. 5b). On the other hand, the salt walls and diapirs, still recognizable within the central part of the basin, represent structures already close to paleosurface at the end of the Triassic. Furthermore, seismic and well data indicate that the Permian salt extruded and was even partially re-deposited during latest Middle-Late Triassic (Keuper) time. This is supported by presence of the Permian spores within the Keuper salt-rich layers (Trusheim, 1960) and by direct structural relation between the Keuper salt-rich layers and the Permian salt structures in the GG (Maystrenko et al., 2005a, b). The Triassic has been considered only as one step for our reconstruction as the available dataset does not allow differentiation of this interval. We are aware that part of the Triassic deposits, mainly the Keuper salt, has been mobilized post-depositionally. However, it is impossible to distinguish the proportion of Keuper salt versus Permian salt in the present day salt structures. Therefore, this component of Keuper salt is not considered in the reconstructed thickness map of the Triassic.

The present-day thickness map of the Jurassic shows the distribution of sediments remaining after the Late JurassicEarly Cretaceous erosion (Fig. 5 c). Figure 5 c illustrates that the centre of sedimentation shifted from the central part towards adjoining areas when compared with the Triassic (Fig. 5a), forming two centres, one in the north-west and one in the south-east. The Central Glueckstadt Graben area is characterized by a lack of Jurassic sediments or by relatively thin deposits reaching less than $400 \mathrm{~m}$ thickness (Fig. 5c). The Westholstein Through, located at the NW margin of the Central Glueckstadt Graben (Fig. 5c), has an estimated width of about $20 \mathrm{~km}$ and is filled with relatively thick Jurassic sediments (up to $2500 \mathrm{~m}$ ). As a counter part, the Hamburg and Eastholstein troughs formed at the SE margin of the Triassic Graben. The Eastholstein syncline is characterized by a SW-NE elongated band of sediments along the marginal salt wall, where the Jurassic is locally 1800 - $2200 \mathrm{~m}$ thick with an average thickness between 1000 and $1200 \mathrm{~m}$. The complex Jurassic thickness pattern with almost circular and elongated zones near Hamburg defines the extent of the Hamburg Trough which is filled by up to $1600 \mathrm{~m}$ of Jurassic sediments. The restoration of Jurassic sediments prior to Late Jurassic-Early Cretaceous erosion is a more problematic task than the re-establishment of the Triassic thickness map. In some parts of the $\mathrm{GG}$, the entire Jurassic and lowermost Cretaceous deposits are missing. From the seismic data, it is not possible to decide whether the unconformity is erosive or non-depositional within the areas where sediments are absent. In order to produce a reconstructed thickness map of the Jurassic (Fig. 5d), a constant value of $250 \mathrm{~m}$ was added to the present-day thickness map. The constant value of
$250 \mathrm{~m}$ was chosen as a first-order approximation to cover the entire region by sediments rather than to provide the true amount of the eroded sediments. From the seismic data discussed in Maystrenko et al. (2005b) it is inferred that the remaining sediments represent areas where sedimentation and subsidence were most intensive and were strongly controlled by withdrawal of the Permian salt from the source layer. Therefore, the erosional features did not alter the regional trend of thickness distribution of the Jurassic. Consequently, the reconstructed map in Fig. $5 \mathrm{~d}$ can be taken as a qualitative approximation of the sediment distribution prior to erosion.

The Lower Cretaceous sediments show a wider distribution than the Jurassic, covering most salt structures already existing at the beginning of the Cretaceous (Fig. 5e). The regional trend shows minor subsidence after the Late JurassicEarly Cretaceous erosion, however, locally thickened Lower Cretaceous deposits are observed around salt structures within the Westholstein and Hamburg troughs. The thickness of the Lower Cretaceous sequence increases from less than $90 \mathrm{~m}$ to more than $500 \mathrm{~m}$ within the Westholstein and Hamburg Troughs (Fig. 5e). A large zone of thickened Lower Cretaceous in the Westholstein Trough stretches in SW-NE direction between two elongated salt walls. Probably, this thickening is related to the simultaneous growth of salt walls. In contrast, within the Hamburg Trough, the Lower Cretaceous thickening zone is almost circular, reflecting sedimentation in the vicinity of a circular shaped salt diapir. In general, the thickness of sediments in the Westholstein and Hamburg troughs indicates the continuation of salt movements into the Early Cretaceous, following the strong Jurassic salt activity in these areas. Reestablishment of the regional Lower Cretaceous thickness map was done by filling those areas that were pierced by postCretaceous salt walls and diapirs (Fig. 5f). Consequently, the difference between reconstructed (Fig. 5f) and present-day thickness maps (Fig. 5e) of the Lower Cretaceous consists only in the absence of pierced areas.

The thickness of the Upper Cretaceous indicates regional subsidence with local disturbances due to salt tectonics (Fig. $5 \mathrm{~g}$ ). This is expressed in small variations in thickness (between 500 and $700 \mathrm{~m}$ ) across the entire study area. However, a pronounced thickening of up to 1400 - $1600 \mathrm{~m}$ occurs within a narrow band in the Westholstein Trough, while a less intense thickening is observed within the Eastholstein Trough. In the Hamburg Trough, the relatively thick Upper Cretaceous (1200 - $1300 \mathrm{~m}$ ) forms two synclines, which are almost symmetrically situated to the west and the east of a salt diapir (Fig. $5 \mathrm{~g}$ ). The structural features of the isochores indicate that deposition of thick Upper Cretaceous occurred simultaneously with salt movements within relatively shallow rim synclines (e.g. Fig. 4). The reconstructed thickness map of the Upper Cretaceous is shown in Fig. 5h. There are no indications of strong salt diapirism during the Late Cretaceous in the area under consideration according to seismic data. 
Therefore, the presence of holes due to piercing by salt walls and diapirs must be a result of post-Cretaceous salt movements. As for the Lower Cretaceous, post-depositional gaps in pierced regions were closed by interpolation over those areas. Upper Cretaceous sediments were postdepositionally deformed, uplifted and partially eroded within the crest of some salt structures (e.g. Figs 3 and 5). These features are easily seen on the present-day thickness map (Fig. $5 \mathrm{~g}$ ) by locally decreased thicknesses. These areas were reinterpolated and the resultant reconstructed map (Fig. 5h) shows that the distribution pattern of the Upper Cretaceous is characterized by an almost constant thickness. The remaining two areas of decreased thickness correspond to two salt structures, which were active during the Late Cretaceous within the Westholstein and Hamburg troughs (Fig. 5h).

The present-day isopach map of the Paleogene (Fig. 5i) shows thickness maxima in the West-, Eastholstein and Hamburg troughs. This indicates that Paleogene subsidence occurred mainly within the marginal sub-basins, while it was much less intense in the central part of the GG. As with the Jurassic, Lower Cretaceous and Upper Cretaceous, the centres of deposition are located in the marginal troughs. However, the thick Paleogene extends further west within the Westholstein Trough compared to the Jurassic and Cretaceous. The Paleogene in the Westholstein Trough reaches locally a thickness of 2500-3000 m, showing a strong isopach gradient from the salt wall towards the centres of the rim synclines. In the Eastholstein and the Hamburg troughs, the entire area of the former Jurassic and Cretaceous troughs was likewise reaffected by increased rates of subsidence with the strongest thickness gradient in the south-western part of the Hamburg Trough. Two circularly thickening zones are visible within the western part of the Hamburg Trough, where the highest isopach values vary between 2300 and $2900 \mathrm{~m}$. The Eastholstein Trough is a pronounced NW striking zone of thick Paleogene with a maximum thickness between 1300 and $1700 \mathrm{~m}$. The area of the Central Glueckstadt Graben is characterized by narrow bands of a reduced Paleogene thickness (Fig. 5i): there, the Paleogene varies from $0-200 \mathrm{~m}$ above the crests of salt structures and increases to $400-900 \mathrm{~m}$ between the salt structures. The reduced Paleogene thickness above the crests of salt walls indicates continued rise of salt structures during the Paleogene or/and the post-Paleogene erosion of the crests. The reconstruction of Paleogene thickness (Fig. 5j) mainly consists in the re-establishment of those parts eroded from the crest of salt structures prior to the Neogene. Thus, the thinning of the Paleogene in the crests of salt structures is smoothed on the reconstructed thickness map (Fig. 5j) in comparison to the present-day thickness map (Fig. 5i).

The present-day distributions of sediments at different stratigraphic levels (Fig. 5) show that the centre of sedimentation moved away from the central part of the original Triassic trough towards its margins (Fig. 6). It is obvious that the marginal troughs (Westholstein, Eastholstein and Hamburg) are separated by thick Triassic (mainly Keuper) deposits which are strongly thickened towards the axial part of the GG (Fig. 5a). On the other hand, the area of the Central Glueckstadt Graben is characterized by relatively thin Cretaceous and Cenozoic sediments (Figs 5e, $\mathrm{g}$ and i) and partly by the absence of the Jurassic (Fig. 5c). Furthermore, the distribution of thickness maxima demonstrates that the thick Jurassic is covered by thickened Cretaceous, Paleogene and Neogene but without vertical alignment of those axial parts within the marginal troughs (Fig. 6). Thus, figure 6 suggests that a greater amount of subsidence occurred close to the active salt structures, and may have resulted in a gradual depletion of Permian salt from the source layer.

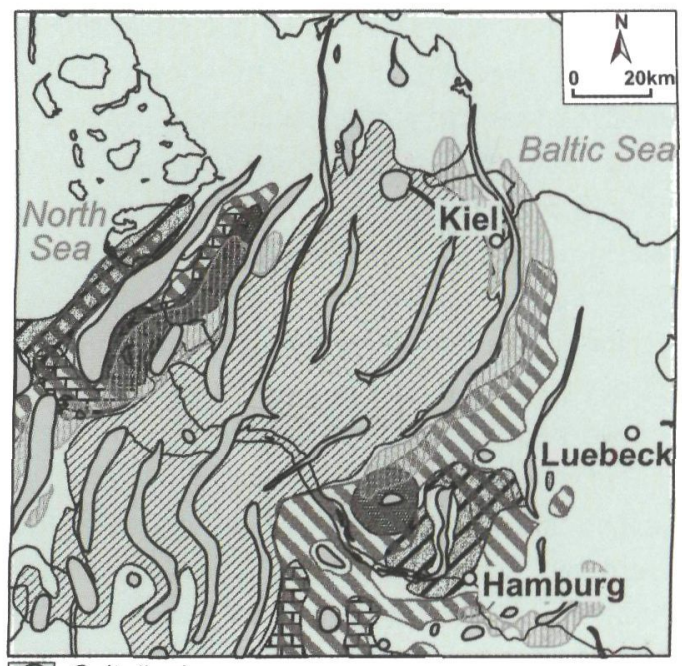

O]-Salt diapirs

Centres of maximum sedimentation during:

V- Quaternary-Neogene; $\mathbf{V}$ - Paleogene;

- Late Cretaceous;

揹用 - Jurassic:

- Early Cretaceous: DZ-Triassic.

Fig. 6. Outlines of the depocentres indicating the shift of deposition with time from the central part in the Triassic to marginal parts in the Quaternary-Neogene within the Glueckstadt Graben (modified after Maystrenko et al., 2005a).

\section{Backward modelling}

Figures 7 and 8 illustrate the outcomes from the 3D backward modelling of the spatial and temporal evolution of the salt structures in the GG. Figure 7 illustrates the modelled thickness of the Permian salt for the present-day state and for different stages of backstripping. One of the most remarkable results is related to the expansion of the depletion zone shown by white colour in Fig. 7. It can be seen that the Permian salt layer was almost depleted within the central part of the basin in the Triassic (Fig. 7f). A small area of reduced salt thickness is also seen west of Hamburg (Fig. 7f), indicating Triassic salt movements within the Hamburg Trough. A second feature is the increasing number of linear zones of increased salt 


\section{Present day}

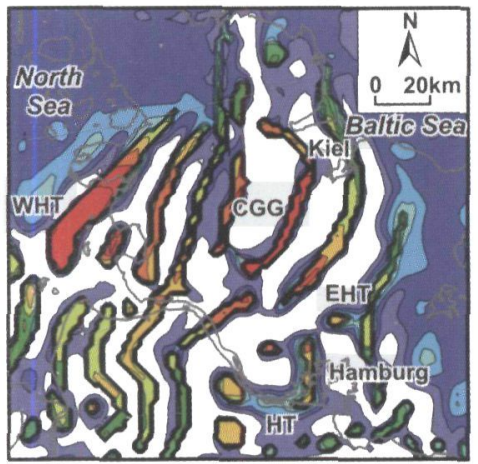

\section{End of the Early Cretaceous}

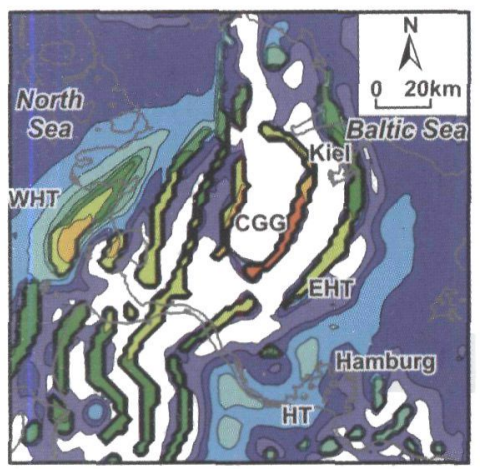

d.

\section{End of the Paleogene}

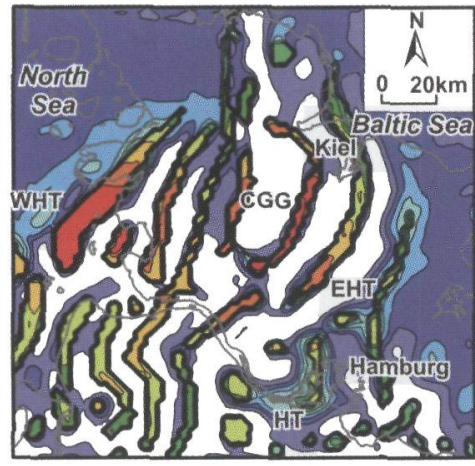

b.

\section{End of the Jurassic}

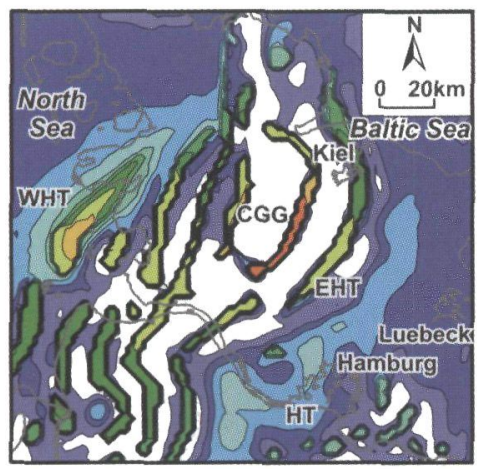

e.

\section{End of the Late Cretaceous}

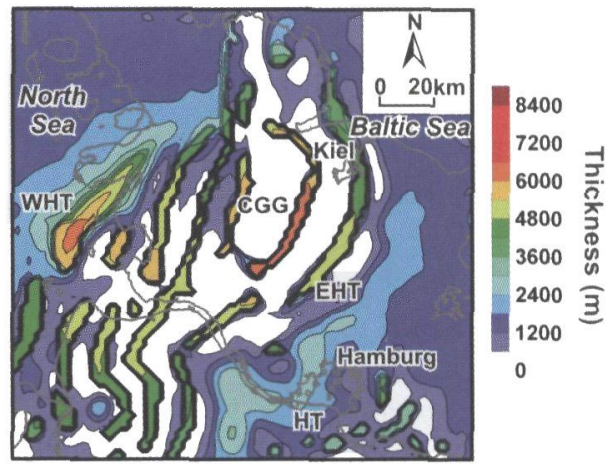

\section{End of the Triassic}

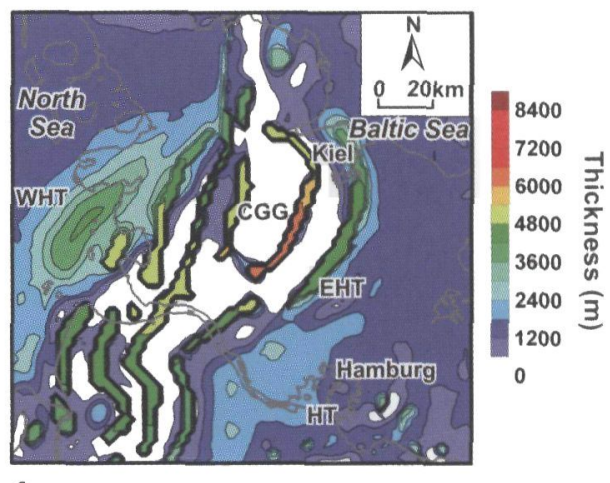

Fig. 7. Isochore maps of the Permian salt from the end of the Triassic ( $f$ ) to present-day (a) based on backward modelling. Gradual migration of the depletion zone from the central part of the original Central Glueckstadt Graben (f) towards its margins (a) is shown by white colour.

CGG - Central Glueckstadt Graben, EHT - Eastholstein Trough, HT - Hamburg Trough, WHT - Westholstein Trough.

thickness shown in green, yellow or different shades of red. These zones represent growing salt structures. Some of these salt structures were already in place in the Central Glueckstadt Graben, whereas the marginal troughs (West-, Eastholstein and Hamburg) are characterized by locally increased salt thickness related to salt movements. During the Jurassic, depletion of the salt layer affected the SW and NE margins of the Central Glueckstadt Graben (Fig. 7e). Accordingly, the zone of reduced thickness within the Hamburg Trough became wider in comparison to Triassic times (cf. Figs $7 f$ and 7e). Between the Jurassic (Fig. 7e) and the Lower Cretaceous (Fig. 7d), there is almost no difference in most parts of the basin, indicating minor salt activity during the Early Cretaceous. During the Late Cretaceous, only some reductions of salt thickness occurred within the Westholstein and Hamburg troughs (Fig. 7c). The map of salt thickness at the end of the Paleogene (Fig. 7b) demonstrates that the depletion of the Permian salt layer occurred mainly within the marginal troughs. Thus, the thickness of the salt was strongly reduced within the Westand Eastholstein troughs. On the other hand, depletion of the salt layer within the Hamburg Trough was more intense at its western and eastern margins than in the central part (Fig. 7b). Further expansion of the salt depletion zone towards the basin flanks took place during the Quaternary-Neogene (Fig. 7a). Well data demonstrate that some of the marginal salt walls are covered by very thin Quaternary deposits up to $25 \mathrm{~m}$ thick, indicating that these salt structures may have been active until today. Moreover, Lehne and Sirocko (2005) reported that the GG is affected by recent vertical movements caused by actively rising salt structures and faults.

$3 \mathrm{D}$ views of the top of the Permian salt for the different backstripping levels are plotted in Fig. 8 to illustrate the substantially changing salt structure distribution from the end of the Triassic (Fig. 8f) up to present day (Fig. 8a). The results support the conclusion that initial salt movements took place during Middle-Late Triassic within the central part of the GG (Fig. 8f). Figure $8 \mathrm{f}$ also indicates the development of shallow salt anticlines within the marginal troughs in the Triassic. Following this initiation, strong salt tectonics occurred at the margins of the former Triassic Graben in the Jurassic (Fig. 8e), while during the Cretaceous-Tertiary, additional growth of salt structures took place within the marginal troughs (Figs $8 \mathrm{a}-\mathrm{d}$ ). In addition, the central salt walls experienced a reactivation in the Cenozoic. The $3 \mathrm{D}$ geometries of the reconstructed salt structures in Fig. 8 correlate spatially with the reduction of the salt thickness (Fig. 7) from the end of the 


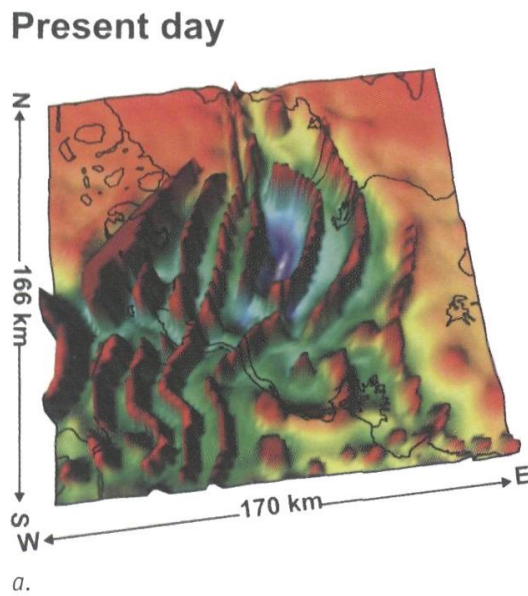

End of the Paleogene

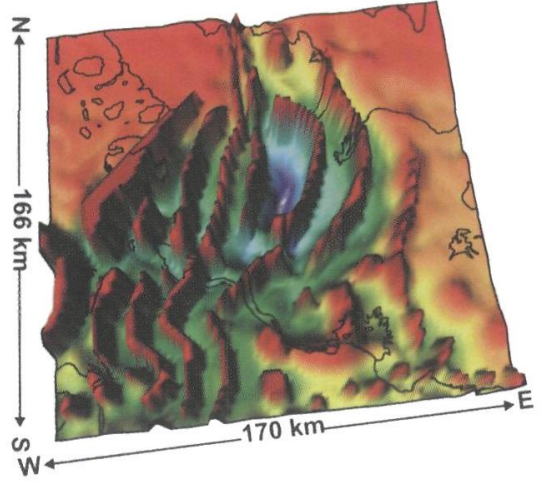

b.
End of the Late Cretaceous

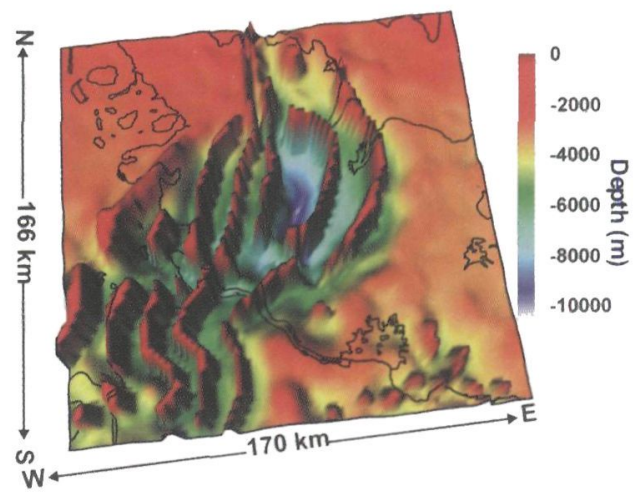

C.

\section{End of the Early Cretaceous End of the Jurassic}
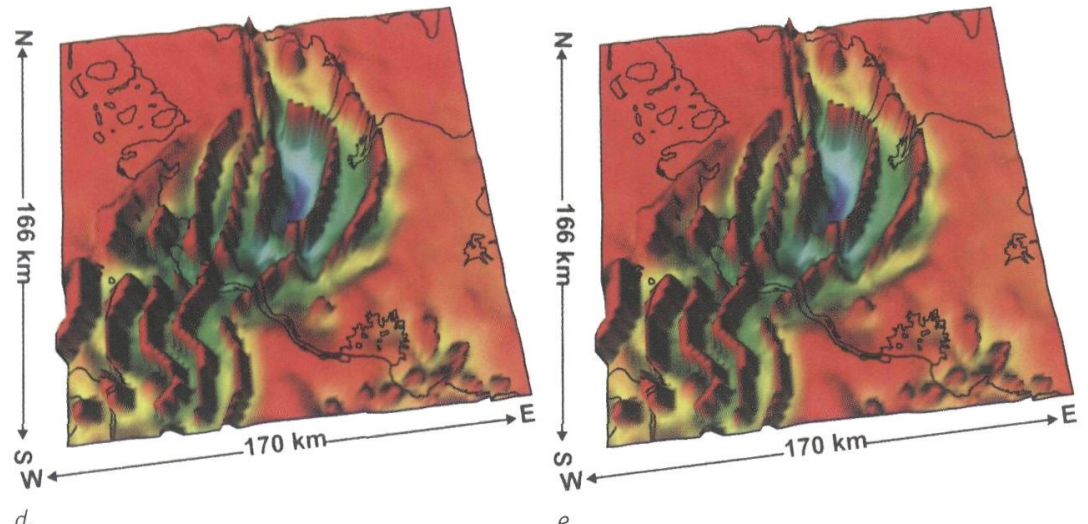

\section{End of the Triassic}

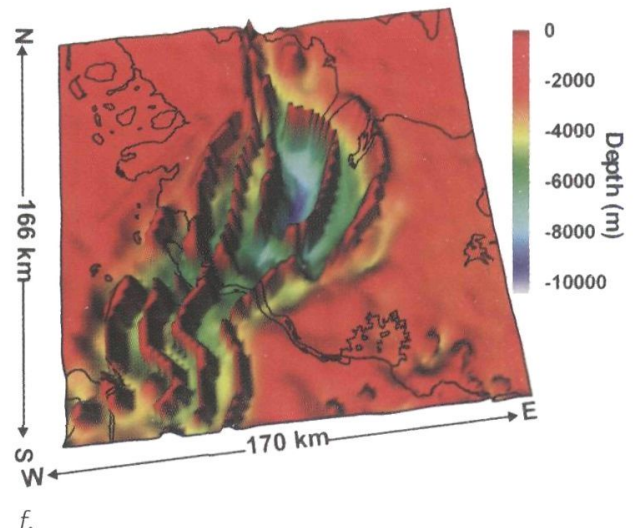

Fig. 8. 30 views of the top of the Permian salt at the different stratigraphic intervals showing the evolution of salt structures with time. The number of discordant salt structures increases with time from the end of Triassic (piercing structures only in the central part) to the present day (piercing structures affect the entire Glueckstadt Graben).

Triassic to the present-day. In other words, 3D backward modelling provides evidence for a continued depletion of the Permian salt layer progressing from the central part of the basin outwards to the basin flanks.

\section{Discussion}

The results of the modelling reveal the thickness distribution of the Permian salt within the GG from the end of the Triassic (Fig. 7f) to present day (Fig. 7a). In addition, our study has several important implications for salt behaviour under different tectonic settings. During the Triassic, the first stage of diapirism occurred within the central part of the GG (Figs $7 f$ and $8 f$ ). This major phase of growth of salt structures could have been triggered by Triassic extension that culminated during the Keuper (e.g. Brink et al., 1990, 1992; Kockel, 2002; Maystrenko et al., 2005a, b). This is consistent with the assumed regional stress field during the Triassic, when a series of approximately north-south striking graben structures formed in the other parts of the CEBS. Accordingly, the stress field for this period was characterized by almost east-west extension as appears from the regional structural analysis of Central Europe
(Ziegler 1990). Best et al. (1983), Vajbaek (1990), Ziegler (1990) and Kokcel (2002) identified an initial stretching event in the Early Triassic (Buntsandstein) for the Horn Graben and the GG. Triassic extension culminated, together with the main phase of salt diapirism, in the Middle-Late Triassic (Keuper) in the Horn Graben and the GG. Middle-Late Triassic normal faulting has been documented by Baldschuhn et al. (1996, 2001), Kockel (2002) and Maystrenko et al. (2005b) in NW Germany. This pulse of extension has been observed in the NE German Basin, where strong salt movements and coeval deposition of Keuper is seen within the N-S striking Rheinsberg Trough (Scheck et al., 2003b).

Regional extension, responsible for normal faulting of the salt base, may have triggered reactive diapirism and caused the formation of the deep primary rim synclines. Once the salt structures had reached critical size, buoyancy forces (e.g. Schultz-Ela et al., 1993) supported their continued growth until the Jurassic when extension-induced regional stresses once more affected the GG. Accordingly, the next pulse of salt activity, in the Jurassic (Figs 7e and 8e), correlate temporally with extensional tectonics in the south of the GG, where accelerated subsidence is observed within the Pompeckj Block 
and the Lower Saxony Basin (Kockel, 2002). In most cases, Jurassic salt movements caused the formation of secondary rim synclines adjacent to the Keuper primary depocentres. Note that the Jurassic pulse of salt tectonics did not provoke the formation of completely new salt structures (cf. Figs 7e and 7f) but caused the additional growth of the pre-existing Triassic ones. During the Jurassic, some of the Keuper-aged concordant salt structures became discordant due to salt-induced erosion at the crests of the former salt anticlines (cf. Figs $8 \mathrm{e}$ and $8 \mathrm{f}$ ).

The results of the modelling indicate that very little salt activity took place during the Early Cretaceous (cf. Figs $7 \mathrm{~d}$ and $7 \mathrm{e})$. However, the Jurassic salt-induced deformation persisted in the earliest Cretaceous (the Berriasian and the Valanginian) when salt continued to move close to the former Jurassic salt structures. This can be inferred from structural data in the Geotectonic Atlas of NW Germany (Baldschuhn et al., 2001) and from the present-day thickness map of the Lower Cretaceous (Fig. 5). Possible reasons are not resolved from our dataset and could be related to gravity-driven salt rise or to regional tectonic influence. During the post-Valanginian, almost all salt stocks and walls were covered by Lower Cretaceous (Hauterivian-Albian) deposits, the almost constant thickness of which indicate an absence of strong salt movements in the GG. Similar remarks can be made for the lower part of the Upper Cretaceous which is also characterized by approximately constant thickness. Therefore, salt movements ceased during the late Early Cretaceous-early Late Cretaceous. Possible reasons for the interruption of the salt movements could be depletion of the source salt layer near the salt structures and/or tectonic quiescence during this time. Salt movements were renewed by compressional forces during the latest Late Cretaceous-Early Cenozoic especially within the marginal troughs, indicating that sufficient thickness of the source layer remained there. Vendeville et al. (2002) demonstrated the importance of early or late regional extension and shortening in driving saltstructures evolution in NW Germany. Furthermore, Stovba \& Stephenson (2003) have observed a similar situation in the Dniepr-Donets Basin where many salt structures display renewed growth after a regional interruption of salt movements. They proposed that an increasing thickness of overburden led to a mechanical balance and cessation of salt movement until the forces induced by tectonic reactivation once again upset this unstable equilibrium (Stovba \& Stephenson, 2003). It is important to note that there is no evidence for tectonic activity in the GG during the late Early Cretaceous-early Late Cretaceous. Therefore, our study supports the concept of tectonically induced salt movements which can be interrupted during the absence of tectonic forces (Vendeville et al., 2002; Stovba \& Stephenson, 2003). Consequently, the lack of strong salt movements is in good agreement with the tectonically silent regime in the GG during the late Early Cretaceous-early Late Cretaceous.
In the Hamburg Trough, thickening of the uppermost Upper Cretaceous-Lower Paleogene (Figs 4, 5g, i) implies that salt was active during this period, probably as a result of compressional stresses related to the Alpine Orogeny (Kockel, 2002). Possibly the thick-skinned deformations observed at the Aller Lineament in the latest Late Cretaceous-Early Cenozoic, (Mazur \& Scheck-Wenderoth, 2005) were transmitted northward into the overburden of the GG causing salt movements without involving the salt base into the deformation. Similar observations have been documented by Scheck et al. (2003a, b) in the NE German Basin where strain localization along the SW margin (Gardelegen Fault) may have propagated into the salt cover of the basin, so that the resulting folding was balanced by viscous salt flow into the anticlines.

The next phase of Paleogene-Neogene salt withdrawal led to growth of $\mathrm{N}-\mathrm{S}$ oriented salt structures mainly at the margins of the basin (Figs $7 \mathrm{a}, \mathrm{b}$ and $8 \mathrm{a}, \mathrm{b}$ ). This phase of salt tectonics correlates temporally with normal faulting in the overburden and salt base (Maystrenko et al., 2005a, b). This indicates a renewed change in tectonic regime after Late Cretaceous-Early Cenozoic compression.

Though our approach yields solid results on the main controlling factors for the evolution of the GG at a regional scale, some limitations of the method have to be mentioned for completeness. The results of the salt redistribution depend strongly on the input data set, especially the reconstructed thickness maps for the backward modelling and the geometry of the salt base. Another sensitive parameter for the outcome of the modelling is the original amount of Permian salt. The latter is dependent on the potential volume loss due to dissolution of salt, a process which has been considered with limited accuracy only. Additionally, the re-established distribution of the Keuper sediments has to be corrected for postdepositional Keuper salt movements at the post-Triassic evolution stage of the GG. In order to avoid possible mistakes, the reconstructed thickness maps were made by using all available data and the shape of the salt base was predefined with some approximation beneath the salt structures. This part proved to be a difficult task as the salt base beneath the salt structures often is poorly imaged on seismic data. Especially in the central part of the GG, no deep wells reach this level and the base salt surface in the model remains an approximation.

To remove these uncertainties, additional data would be required (seismic lines and deep wells). For instance, a prestack migration should be applied to all seismic lines crossing salt walls in order to resolve the seismic image beneath salt structures and additional borehole data and seismic lines are needed for accurate correlation of reflections within the areas strongly affected by salt tectonics. For this reason, some simplifications were used in the modelling process. However, 3D structural modelling provides quantitative results within the limitations discussed above. 


\section{Conclusions}

The results of 3D backward modelling demonstrate that the formation of the deep Central Glueckstadt Graben and the subsequent Jurassic-Cenozoic marginal troughs (Westholstein, Eastholstein and Hamburg) was strongly controlled by salt movements through time. In summary, it can be stated that the development of the depletion zone of the Permian salt through time (Fig. 7) is in agreement with the observed distribution of the maximum subsidence centres of the different stratigraphic units (Figs 6). This points to the conclusion that salt removal seated the accommodation space for local sediment accumulation. In the central part of the GG, the depletion occurred already in the Triassic and perfectly correlates with the thickest Triassic (cf. Figs $7 f$ and 5a). During the Jurassic, Cretaceous and Cenozoic, the areas of depleted Permian salt shifted towards the basin flanks and the same shift is observed for the centres of maximum sediment deposition. Only minor isolated salt pillows persisted within the central part of the basin and have locally fed salt walls and diapirs during postTriassic time. As indicated by thickness maxima (Fig. 6), the sedimentation centres for each periods are always located above the zone of reduced or depleted Permian salt (cf. Figs 6 and 7). Thus, the results of the modelling strongly support the conclusion that salt withdrawal has played an important role during the Meso-Cenozoic basin evolution and that the effects of the salt-driven subsidence during the Meso-Cenozoic may be considered as one of the main controlling factors for the formation of the deep Central Glueckstadt Graben and the subsequent Jurassic-Cenozoic marginal troughs (Hamburg, Eastand Westholstein). In other words, the progressive depletion of the Permian salt layer, from the central part towards the margins, created the large part of the accommodation space for sedimentation in addition to tectonic subsidence in the GG.

The results of our study indicate a good correlation between the main phases of salt movements and tectonic events, implying tectonically induced salt activity in the area under consideration. During the Triassic, the first stage of salt movements occurred within the Central Glueckstadt Graben. Regional extension, responsible for faulting of the base salt, may have triggered reactive diapirism and caused the formation of the deep primary rim synclines. Once the salt structures had reached the critical size, buoyancy forces supported their continued growth until the Jurassic when extension-induced regional stresses once more affected the GG. The results of the modelling demonstrate very little salt activity during the late Early Cretaceous-early Late Cretaceous when the area of the GG was tectonically silent. Therefore, our study supports the concept of tectonically induced salt movements which can be interrupted during tectonically silent intervals. Salt movements were reactivated in the marginal troughs (Hamburg, East- and Westholstein) by compressional forces during the latest Late Cretaceous-Early Cenozoic. The youngest phase of Paleogene-Neogene salt withdrawal led to the growth of almost N-S oriented salt structures mainly at the margins of the basin. This phase of salt tectonics correlates temporally with almost W-E extension, indicating a renewed change in tectonic regime after Late Cretaceous-Early Cenozoic compression.

\section{Acknowledgements}

The authors would like to acknowledge the financial help from the German Research Council, which has been provided within the DFG-SPP 1135 'Dynamics of sedimentary systems under varying stress conditions by example of the Central European Basin system'. Our gratitude is also extended to the DGMK as representative of the German 0il and Gas Industry for data support and allowance for publishing industrial data (DGMK project 577). We are grateful to the company Nord-Express (and personally grateful to Mykola Golyarchuk) for free-of charge use of the software for digital processing of seismic data (SPS-PC). Special thanks go to Björn Lewerenz, for his helpful assistance in many of the numerical modelling parts of this study. We thank Harry Doust and Mark Geluk for their valuable and constructive reviews, which helped to improve the quality of the manuscript significantly.

\section{References}

Baldschuhn, R., Binot, F., Fleig, S. \& Kockel, F. (eds), 2001. Geotektonischer Atlas von Nordwest-Deutschland und dem deutschen Nordsee-Sektor Strukturen, Struckurenwicklung, Paläogeographie. Geologisches Jahrbuch A 153: 1-88, 3 CD-Rs.

Baldschuhn, R., Frisch, U. \& Kockel, F. (eds), 1996. Geotektonischer Atlas von NW-Deutschland $1: 300,000.4$ pp., 65 maps, Bundesanstalt für geowissenschaften und Rohstoffe, Hannover.

Bayer, U., Scheck, M., Rabbel, W., Krawczyk, C.M., Götze, H.-J., Stiller, M., Beilecke, Th., Marotta, A.M., Barrio-Alvers, L. \& Kuder, J., 1999. An integrated study of the NE German Basin. Tectonophysics 314: 285-307.

Best, G., Kockel, F., Schoeneich, H., 1983. Geological history of the southern Horn graben. Geologie en Mijnbouw 62: 25-33.

Betz, D., Führer, F. \& Plein, E., 1987. Evolution of the lower Saxony basin. Tectonophysics 137: 127-170.

Boigk, H., 1981. Erdöl und Erdölgas in der Bundesrepublik Deutschland: Erdölprovinzen, Felder, Förderung, Vorräte, Lagerstättentechnik. Germany, Stuttgart, Enke: 330 pp.

Brink, H.J., Dürschner, H. \& Trappe, H., 1992. Some aspects of the late and post-Variscan development of the Northwestern German Basin. Tectonophysics 207: 65-95.

Brink, H.J., Franke, D., Hoffmann, N., Horst, W. \& Oncken, O., 1990. Structure and evolution of the North German Basin. In: R. Freeman, P. Giese \& St. Mueler (eds): The European Geotraverse: Integrative Studies. European Science Foundation (Strasbourg): 195-212. 
Britze, P. \& Japsen, P., 1991. The Danish Basin.Triassic. Isochore map: Danmarks Geologiske Undersogelse (DGU) Miloeministeriet, Copenhagen, DGU map series no. 31, 1 sheet, scale $1: 400,000$.

Clausen, O.R. \& Pedersen, P.K., 1999. The Triassic structural evolution of the southern margin of the Ringkøbing-Fyn-High, Denmark. Marine and Petroleum Geology 16: 653-665.

Dadlez, R., 2003. Mesozoic thickness pattern in the Mid-Polish Trough. Geological Quarterly 47 (3): 223-240.

Daudre, B. \& Cloetingh, S., 1994. Numerical modelling of salt diapirism: influence of the tectonic regime. Tectonophysics 240: 59-79.

Erratt, D., Thomas, G.M. \& Wall, G.R.T., 1999. The evolution of the Central North Sea Rift. In: Fleet, A.J. \& Boldy, S.A.R., (eds): Petroleum geology of Northwest Europe; proceedings of the 5th conference. The Geological Society of London, London, United Kingdom: 63-82.

Evans, D., Graham, C., Armour, A. \& Bathurst, P., 2003. The Millennium Atlas: Petroleum geology of the central and northern North Sea. The Geological Society of London (London): $990 \mathrm{pp}$.

Garetsky, R.G., Ludwig, A.O., Schwab, G. \& Stackebrandt, W. (eds), 2001. Neogeodynamics of the Baltic Sea depression and adjacent areas. Brandenburgische Geowissenschaftliche Beiträge 1-2001: 47 pp, 8 maps.

Guglielmo, G.J., Vendeville B.C. \& Jackson M.P.A., 1999. Isochores and 3-D visualization of rising and falling salt diapirs. Marine and Petroleum Geology 16: 849-861.

Ismail-Zadeh, A., Tsepelev, I., Talbot, C. \& Korotkii, A., 2004. Threedimensional forward and backward modelling of diapirism: numerical approach and its applicability to the evolution of salt structures in the Pricaspian basin. Tectonophysics 387: 81-103.

Jaritz, W., 1969. Epiorogenese in Nordwestdeutschland im höheren Jura und in der Unterkreide. Geologische Rundschau 59, 1 Taf.: 114-124.

Jaritz, W., 1980. Einige Aspekte der Entwicklungsgeschichte der nordwestdeutschen Salzstöcke. Zeitschrift der Deutschen Geologischen Gesellschaft 131, 8 Abb: $387-408$

Jordan, H. \& Kockel, F., 1991. Die Leinetal-Structur und ihr Umfeld - ein tektonisches Konzept für Südniedersachsen. Geologisches Jahrbuch A 126: 171-196.

Jordt, H., Faleide, J.I., Bjerlykke, K. \& Ibrahim, M.T., 1995. Cenozoic sequence stratigraphy of the central and northern North Sea Basin: tectonic development, sediment distribution and provenance areas. Marine and Petroleum Geology 12: 845-879.

Kaus, B.J.P. \& Podladchikov, Y.Y., 2001. Forward and reverse modeling of the three-dimensional viscous Rayleigh-Taylor instability. Geophysical Research Letters 28: 1095-1098.

Kockel, F., 2002. Rifting processes in NW-Germany and the German North Sea Sector. Geologie en Mijnbouw 81: 149-158.

Kockel, F., 2003. Problems of diapirism in northern Germany. Geologos 6: 57-88. Koyi, H., 1998. The shaping of salt diapirs. Journal of Structural Geology 20: 321-338.

Koyi, H., Jenyon, M.K. \& Petersen, K., 1993. The effects of basement faulting on diapirism. Journal of Petroleum Geology 16 (3): 285-312.

Krzywiec, P., 2004. Triassic evolution of the Klodawa salt structure: basementcontrolled salt tectonics within the Mid-Polish Trough (Central Poland). Geological Quarterly 48: 123-134.
Lamarche, J. \& Scheck-Wenderoth, M., 2005. 3D structural model of the Polish Basin. Tectonophysics 397: 73-91.

Lehne, R. \& Sirocko, F., 2005. Quantification of recent movement potentials in Schleswig-Holstein (Germany) by GIS-based calculation of correlation coefficients. International Journal of Earth Sciences 94: 1094-1102.

Lokhorst, A. (ed.), 1998. The Northwest European gasatlas. Netherlands Institute of Applied Geoscience TNO (Haarlem); ISBN 90-72869-60-5.

Maystrenko, Y., Bayer, U. \& Scheck-Wenderoth, M., 2005a. The Glueckstadt Graben, a sedimentary record between the North and Baltic Sea in north Central Europe. Tectonophysics 397: 113-126.

Maystrenko, Y., Bayer, U. \& Scheck-Wenderoth, M., 2005b. Structure and evolution of the Glueckstadt Graben due to salt movements. International Journal of Earth Sciences 94: 799-814.

Mazur, S. \& Scheck-Wenderoth, M., 2005. Constraints on the tectonic evolution of the Central European Basin System revealed by seismic reflection profiles from Northern Germany. Netherlands Journal of Geosciences / Geologie en Mijnbouw 84: 389-401.

Mazur, S., Scheck-Wenderoth, M. \& Krzywiec, P., 2005. Different modes of the Late Cretaceous - Early Tertiary inversion in the North German and Polish basins. International Journal of Earth Sciences 94: 782-798.

Moeller, J.J. \& Rasmussen, E.S., 2003. Middle Jurassic - Early Cretaceous rifting of the Danish Central Graben. In: Ineson, J.R. \& Surlyk, F. (eds): The Jurassic of Denmark and Greenland. Geological Survey of Denmark and Greenland, Copenhagen: 247-264.

Nielsen, S.B., 2002. A post mid-Cretaceous North Sea model. Bulletin of the Geological Society of Denmark 49: 187-204.

NITG, 2004. Geological Atlas of the Netherlands - onshore (1:1,000,000). Netherlands Institute for Applied Geoscience TNO - National Geological Survey (Utrecht): $103 \mathrm{pp}$.

Oakman, C.D. \& Partington, M.A., 1998. Cretaceous. In: Glennie, K.W., (ed.) Petroleum geology of the North Sea, basic concepts and recent advances (4th edition). Blackwell Scientific Publications, 0xford: 294-349.

otto, V., 2003. Inversion-related features along the southeastern margin of the North German Basin (Elbe Fault System). Tectonophysics 373: 107-123.

Pharaoh, T.C., 1999. Palaeozoic terranes and their lithosphere boundaries within the Trans-European Suture Zone (TESZ): a review. Tectonophysics 314: 17-41.

Poliakov, A.N.B., van Balen, R., Podladchikov, Yu., Daudré, B., Cloetingh, S. \& Talbot, C., 1993. Numerical analysis of how sedimentation and redistribution of surficial sediments affects salt diapirism. Tectonophysics 226: 199-216.

Rodon, S. \& Littke R., 2005. Thermal maturity in the Central European Basin system (Schleswig-Holstein area): results of $1 \mathrm{D}$ basin modelling and new maturity maps. International Journal of Earth Sciences 94: 815-833.

Roemer, M.-M. \& Neugebauer, H.J., 1991. The salt dome problem: a multilayered approach. Journal of Geophysical Research 96: 2389-2396

Sannemann, D., 1968. Salt-stock families in northwestern Germany. In: Braunstein, J. \& 0'Brien, G. (eds): Diapirism and diapirs. AAPG publication: 261-270.

Scheck, M. \& Bayer, U., 1999. Evolution of the Northeast German Basin inferences from 3D structural modelling and subsidence analysis. Tectonophysics 313: 145-169. 
Scheck, M., Bayer, U. \& Lewerenz, B., 2003a. Salt movements in the Northeast German Basin and its relation to major post-Permian tectonic phases results from 3D structural modelling, backstripping and reflection seismic data. Tectonophysics 361: 277-299.

Scheck, M., Bayer, U. \& Lewerenz, B., 2003b. Salt redistribution during extension and inversion inferred from 3D backstripping. Tectonophysics 373 : 55-73.

Scheck, M., Bayer, U., Otto, V., Lamarche, J., Banka, D. \& Pharaoh, T., 2002. The Elbe Fault System in North central Europe - a basement controlled zone of crustal weakness. Tectonophysics 360: 281-299.

Scheck-Wenderoth, M. \& Lamarche, J., 2005. Crustal memory and basin evolution in the Central European Basin System - new insights from a 3D structural model. Tectonophysics 397: 143-165.

Schmeling, H., 1987. On the relation between initial conditions and late stages of Rayleigh-Taylor instabilities. Tectonophysics 133: 65-80.

Schultz-Ela, D., Jackson, M.P.A. \& Vendeville, B., 1993. Mechanics of active salt diapirism. Tectonophysics 228: 275-312.

Sclater, J.G. \& Christie, P.A.F., 1980. Continental stretching: an explanation of the post-Mid-Cretaceous subsidence of the central North Sea basin. Journal of Geophysical Research 85-B7: 3711-3739.

Stovba, S.M. \& Stephenson, R.A., 2003. Style and timing of salt tectonics in the Dniepr-Donets Basin (Ukraine): implications for triggering and driving mechanisms of salt movement in sedimentary basins. Marine and Petroleum Geology 19: 1169-1189

Trusheim, F., 1960. Mechanism of salt migration in North Germany. AAPG Bulletin 44: 1519-1540.

Van Hoorn, B., 1987. Structural evolution, timing and tectonic style of the Sole Pit inversion. Tectonophysics 137: 239-284.

Van Wijhe, D.H., 1987. Structural evolution of inverted basins in the Dutch offshore (North Sea). Tectonophysics 137: 171-219.

Vejbaek, O.V., 1990. The Horn Graben, and its relationship to the 0slo Graben and the Danish Basin. Tectonophysics 178: 29-49.

Vejbaek, 0.V. \& Britze, P., 1994. Top of the pre-Zechstein rocks. Sub- and supercrop map: Danmarks Geologiske Undersogelse (DGU) Miloeministeriet, Copenhagen, DGU map series no. 45, 1 sheet, scale $1: 750,000$.

Vendeville, B.C. \& Jackson, M.P.A., 1992. The rise of diapirs during thinskinned extension. Marine and Petroleum Geology 9: 331-353.

Vendeville, B.C., John, A. \& Jackson, K.G., 2002. A New Interpretation of Trusheim's Classic Model of Salt-Diapir Growth. Gulf Coast Association of Geological Societies Transactions 52: 943-952.

Woidt, W.-D., 1978. Finite element calculations applied to salt dome analysis. Tectonophysics 50: 369-386.

Ziegler, P., 1990. Geological atlas of Western and Central Europe. 2nd ed. Geol. Soc. Publ. House, Bath, Shell International Petroleum Mij. B.v.: 239 pp.

Ziegler, P., 1992. European Cenozoic rift systems. Tectonophysics 208: 91-111. 